1962, the first year of publication of the journal, will be gathered together and, in addition, there will be articles not previously published together with a 15,000-word review presenting a survey of the present state of the art and of the fundamental theories. The price of the supplement will be not more than five dollars. Orders should be sent to the Optical Society of America, 1155 Sixteenth Street, N.W., Washington 6, D.C.

\section{U.K. Courses in Nuclear Energy, 1963-64}

LIsT No. 6 (May 1962) of Nuclear Studies has been compiled by the Science Department of the British Council. This lists courses in pure and applied sciences concerning the use and development of nuclear energy which may be undertaken in the United Kingdom during the year 1963-64. These courses are full-time and are generally of one week or more duration. The information provided by the catalogue includes notes on each of the courses and the institution at which it takes place; also the fee and qualifications required for participation. Further information can be obtained from the Science Department, The British Council, 59 New Oxford Street, London, W.C.1.

\section{Clinical Research in the United States}

The Clinical Research Centers Program, established by the U.S. Public Health Service's National Institutes of Health on the recommendation of Congress, is now in its third year of operation. The programme seeks, through grants to private and public institutions, to enhance and increase the level of clinical research in the United States into the dis. ease of man and into his fundamental biological conditions and problems. A recent report provides a review of the principal developments in the programme and an idea of the types of investigations undertaken by a few of the forty centres established under the programme of the Division of General Medical Sciences, National Institutes of Health, Bethesda, Maryland.

\section{Fibrinolytic Activity of Arterio-Sclerotic Vessels}

Comparatrve studies have been made by $\mathbf{E}$. Perlick and A. Deutschinoff (Hemostase, 1, No. 3; 1961) on both normal and sclerotic aortic and carotid arteries, which show that tissue extracts made from intima and media of arterio-sclerotic vessels have a high tissue fibrinolytic activity when compared with similar extracts from normal vessels. The activators of fibrinolysis found in these vascular extracts exist in the form of a plasminogen activator or proactivator. On the other hand, an increased amount of plasminogen or a plasminogen-like material was also found. A marked increase in tissue fibrinolysis, resulting from arterio-sclerotic changes in the blood vessels, could be the cause of mural and intramural hæmorrhages in the arterio-sclerotic plaques.

\section{Veterinary Research in Japan}

UNDER the title "Deformation of the Vertebral Column in the 'Short-spine Dog' ", Toshihiko Ueshima (University of Tokyo, Japan) has described anatomical studies on four cases and discussed briefly cases in calves of the Oplandske breed in Norway, in turkeys and in a goat (Jap. J. Vet. Res., 9, 155; 1961). Photographs of two dogs and X-ray photographs of the vertebral column of one of them give a clear picture of the condition. There was striking kyphosis in the anterior part of the thoracic segment and in the lumbar segment of the vertebral column, with scoliosis elsewhere. Excess of cartilaginous tissue in vertebræe and other abnormalities are described, with details of histological features and also secondary effects in other adjacent bones.

A new journal, The National Institute of Animal Health Quarterly, from Tokyo, completed its first volume in 1961. The director of the Institute is Susumu Ishii, and there are five branch laboratories of the Institute. In No. 4 of the volume there are eight original articles dealing with infective disease research and with irradiation studies.

\section{Apprenticeship Schemes in the Cambridge Instru- ment Co.}

A BROCHURE prepared by the Cambridge Instrument Co. for the information and guidance of young men contemplating a career in the instrument industry gives a brief summary of the role of instruments in the world to-day, sketches of the Company's history, describes and illustrates some of the instruments the Company makes, and provides information on the types of apprenticeships available. These include craft, technical and graduate apprenticeships. The brochure is attractively illustrated and is obtainable from the Personnel Officer, Cambridge Instrument Co., Ltd., Chesterton Road, Cambridge.

\section{Safety in Laboratories}

IN the article by Prof. R. A. Morton and Dr. J. Glover, entitled "Safety in Laboratories", which appeared on p. 809 of the June 2 issue of Nature, reference is made in the penultimate paragraph to a film, "Safety in the Laboratory", shown by courtesy of Imperial Chemical Industries (General Chemicals), Ltd., at the courses of lectures on "Safety in Laboratories" held at the University of Liverpool during the Lent Term. Imperial Chemical Industries (General Chemicals), Ltd., wish to direct attention to the fact that the title of the film is Black Monday and it was produced by the Imperial Chemical Industries Film Unit. While the film was produced primarily for the Company's own use, the needs of universities, technical colleges and schools were taken into consideration. The film is available on loan through the Imperial Chemical Industries Film Library, Imperial Chemical House, Millbank, London, S.W.l.

\section{Mountbatten Research Studentships in Radio and Electronic Engineering}

THE Council of the British Institution of Radio Engineers is to establish research studentships to encourage fundamental research in radio and electronic engineering. The award will be named after the Institution's charter president, Admiral of the Fleet The Earl Mountbatten of Burma. It is intended to award one studentship in October 1962, the second in October 1963, and thereafter as they become vacant. Each studentship will have an annual value of $£ 500$ plus university or college tuition fees, and will normally be tenable for two years, with a possible extension of one further year. Applications are invited from graduates (or those about to graduate), and the studentships are open to holders of degrees or diplomas in technology (Dip.Tech.) in appropriate subjects from any university or college in the United Kingdom, and can be held in any university or college of advanced technology in the United King. dom which has established research in radio and electronic engineering. Further information can be obtained from the Secretary of the Institution of Radio Engineers, 9 Bedford Square, London, W.C.1. 